\title{
Correlation between Assertiveness and Empathy with Adolescent's Social Adjustment in Social Home of South Jakarta
}

\author{
Elidayani Rodearni Simarmata* and Anizar Rahayu \\ Faculty of Psychology, University of Persada Indonesia Y.A.I, Jakarta, Indonesia \\ *E-mail: elidayani.upiyaijkt@gmail.com
}

\begin{abstract}
This research was conducted to study the correlation between assertiveness and empathy with social adjustment of adolescents in a social home of South Jakarta. Social adjustments include real appearances, adaptation to groups, social attitudes, and personal satisfaction. Assertiveness involves the ability to requests, reject, self-express and participate in the conversation. Empathy consists of aspects cognitive, affective, and communicative (cognition, affection, communication?). Fifty adolescents boys and girls aged $11-22$ who live at Social Home of Bina Remaja in South Jakarta took part in the study were collected using total sampling technique. The participants completed questionnaires measuring social adjustment, assertiveness, and empathy. The results showed that both assertiveness and empathy were positively correlated significant with social adjustment of adolescent's social home in South Jakarta.
\end{abstract}

Keywords: Social Adjustment, Assertiveness, Empathy, Adolescent of Social Home

\section{Introduction}

The adolescence is a change period of growth since the age 10 or 11 to 20 years old. This phase involves a significant change in physical, cognitive and psychosocial aspects that relate each other (Papalia, 2013). There are many claims that adolescents are in the process to become an adult, not only physical but also psychological, and social. The most challenging demand claim is related to social adjustment reaching adult socialization pattern. They have to do it properly unless they to be able having success adult time.

The social adaptation problems that often appear in the time of adolescent who lives in the social home as they have a different background, like the neglected children, orphans, and the broken children, who still have parents or who live in the streets (the homeless drifter). This adolescent often has difficult interaction in the social home. The different atmosphere of the social home with their own house or in the street often makes them difficult to adapt themselves. They often feel not understood by others, getting the less comfortable reaction from their friends, especially for the first time they come. There, they often fail to deliver their wish because of they do not find the same condition like their home or in the streets. In case, having social adjustment ability in receiving and not conflicting with other people, the adolescents need to develop assertiveness. The ability to understand the background differences for them is also needed for their social adaptation because it will decide how they behave in the social situation. In addition, empathy can support them to change their point of view in the previous place to become more flexible because in the social home they get the guidance to be more tolerant and help each other.

It is important taking care the guidance for the adolescent to become a grown-well adjusted adult individual. In fact, many homeless drifters had been preparing the residence in the social home by the government but, some of them choose to flee and not coming back to social home. This problem was influenced by their lack of empathy and low of assertiveness. Therefore, the research about the relationship between assertiveness and empathy with the social adjustment for adolescent need to be done. 
The purposes of the research are:

1. Knowing the correlation between assertiveness with the social adjustment of the adolescents in the social home of South Jakarta.

2. Knowing the correlation between empathy with the social adjustment of the adolescents in the social home of South Jakarta.

3. Knowing the correlation between assertiveness and empathy with the social adjustment of the adolescents in the social home of South Jakarta.

According to Yusuf (2004), a social adjustment is defined as the ability to react appropriately to social reality, situations, and relationships. While Hurlock (2013), states that social adjustment is the success of a person to adjust to others in general and to peer groups in particular.

Hurlock (2013) elaborates that good social adjustment is the result and process of individual self-socialization that occurs during its social development. Several criteria, namely characterize good social adjustment:

a) Real appearance. When the person's social behavior is judged by group standards, meeting group expectations, the individual will be accepted into that member.

b) Adjustment to various groups. Individuals who can adapt well to different groups, both peer groups, and adult groups, are socially regarded as well-adjusted individuals.

c) Social attitude. Individuals should exhibit a favorable attitude toward other persons, to social participation and to roles in social groups, if they are to be perceived as socially accommodating people.

d) Personal satisfaction. To fit socially well, the individual must be content with social contact and the role-played in social situations, both as a leader and as a member.

Schneiders (Mohammad Ali, 2004) argue that there are at least some factors that may affect social adjustment, ie. physical condition, personality, learning process, environment, religion, and culture. Meanwhile, Schneiders (1960) argued that several factors, namely can influence the adjustment of an individual:

a) Physical conditions and factors that affect it, including heredity, physical constitution, health, nervous system, glands, and muscles.

b) Development and maturity, especially intellectual, social, moral and emotional maturity. c) Psychological conditions, including experience, learning, habituation, frustration, and conflict. Environmental conditions, especially the home environment, school families, and communities.

d) Cultural factors, including religion

The word 'assert' is a verb. To assert means to state a fact or belief confidently and forcefully. According to Agustin (Apollo, 2008), assertive behavior describes individual behavior in clearly and expressively communicates the needs, desires, and feelings of other individuals. Assertive behavior will help the individual in conveying opinions, arguments, ideas in everyday activities. Bloom et. al (Zulkaida, 2005) states that assertiveness is an individual effort to communicate something directly and honestly and to make choices without harming other people. Therefore, the characteristics of assertive behavior include expressing ideas, needs and feelings, and defending individual rights in ways, which are not violating the rights of other people. Assertive behavior is usually being honest, being direct, expressive and increasing self-esteem.

According to Palmer and Froehner (2002), assertiveness can be described in several aspects as follows:

a) Demand is the ability of individuals to submit such requests; able to ask for help or help to the person he or she wishes to be, either to a friend or to another person, or to be able to hold the responsibility to his or her friend.

b) Refusal is the ability to present an efficient and honest way of stating 'no', in disagreement with the suggestions or opinions of others.

c) Self Expression is the capacity to express feelings to others honestly and directly about the discomfort of others, such as expressing their annoyance actually to their friends.

d) Praise is the ability to receive and give praise to others in a way, which is appropriate.

e) Role play in the conversation is the capacity to start, to initiate, to participate and to end the conversation effectively.

In Webster's New World Dictionary of the American Language (Supeni, 2014) empathy is defined as intellectual and emotional identification with others. Einsenberg, Fabes, and Hoffman (1996) stated that empathy is an emotional response derived from an understanding of the state and emotions of others alike, sometimes even identical to those experienced by others. According to Hogan 
(Taufik, 2012), empathy is the intellectual or imaginative ability to feel the condition of mind and feelings of others. Furthermore, Taufik (2012) tries to describe empathy as an act of understanding what other people are thinking and feeling, and what the person thinks and feels about the condition that is being experienced by others, without losing his or her control.

To measure it, some aspects that are considered to represent empathy appropriately. Baron and Byrne (2005) suggest that in empathy there are aspects: the cognitive aspect, the individual possessing the ability of empathy to understand what others feel and why it happens to the person. The affective aspect, the empathic individual feels what the other person feels. While Taufik (2012) in his book explains there are four aspects of empathy which is a combination of ideas from contemporary theorists, namely:

a) Cognitive aspects. Understanding the feelings of others that includes the ability to distinguish between self and others, the ability to distinguish the emotional state of others, the ability of social reference and emotional significance, labeling different forms of emotion, and the ability to put yourself into the situation of others in order to know exactly the thoughts and/ or feelings of the person (Eisenberg et al.,1997; Hoffman, 2000).

b) Affective Aspects. The ability to adapt the feelings with what other people are feeling based on experiences that have been encountered in the same conditions and put yourself in the shoes of others (Colley, 1998).

c) Cognitive and Affective Aspects. Multidimensional capabilities that cover both cognitive and affective aspects together cannot be separated in the process of formation of empathy (Richendoller \& Weaver, 1994; Brems, 1989; Davis, 1983; Fesbach, 1975).

d) Communicative Aspects. It means that the behavior which expresses feelings of empathy to others (Bierhoff, 2002).

\section{The Relation of Assertiveness and Empathy to Social Adjustment}

Adolescents in the social home need to adjust to social demands, to be accepted by social groups, this is because teenagers in social institutions have different personal characteristics. Adolescent social adjustment in the social home is not an easy thing to do. Youngsters tend to close themselves for the first time when entering the home due to social situations which are not the same as their previous lives. As a result, adolescents cannot express their emotions appropriately and bravely, cannot voice their desires and opinions openly and honestly; in other words, the teenager is not able to assertive to himself or herself and to others.

According to Rini, Bahri, and Zuliani (2016) someone who can mingle, can express views or personal opinions clearly without hurting the feelings of other individuals. In other words, to be accepted in the environment teenagers should be able to behave assertively. With assertiveness in adolescents, will be able to help them to make a good social adjustment with another individual. Teenagers who are assertive are expected to communicate effectively with their group in social institutions. As adolescents can express themselves and their feelings, communication with peers is better so there are no social constraints in the environment.

Also, the assertiveness is to establish healthy social relationships among adolescents. They are expected to understand other people or often called empathy to adjust socially. The Cohen and Stayer studies (Supeni, 2014) show that subjects who showed high scores on maladjustment and aggression had low scores on empathy. That is why the individuals who have little empathy are difficult to make right adjustments.

Empathy allows individuals to be able to understand other people's intentions, to predict their behavior and to understand emotions that are triggered by their emotions. Adolescents with empathy can comprehend the feelings, to recognize emotions, to align with feelings of others. The ability to understand and feel what is felt by other individuals between adolescents strengthen social relationships. Empathy can also encourage adolescents to change the mindset to be more flexible when they are living in the social home because of the guidance, which is not only to advance but also to change the selfish mindset to be more tolerant of others.

The life of a social home that is very different from life on the streets requires adolescents to adjust themselves to be more advanced and able to follow the rules. When adolescents can to be more honest about their needs, able to express themselves and also to be firm in rejecting negative things that can bring themselves back to the street-like 
environment, they do not feel overwhelmed to behave that they disagree without hurting other people's feelings in the social home. In other words, adolescents who have assertive behavior will have the attitude of understanding feelings and understanding the minds of other individuals, which is called empathy. So, they can communicate their needs both ways. There is no need for misunderstandings that can disrupt their social adjustment in their social life.

The hypotheses in the current study are:

$\mathrm{H}_{1}$ : There is a correlation between assertiveness with the social adjustment of the adolescents in the social home of South Jakarta

$\mathrm{H}_{2}$ : There is a correlation between empathy with social adjustment of the adolescents in the social home of South Jakarta.

$\mathrm{H}_{3}$ : There is a correlation between assertiveness and empathy with the social adjustment of the adolescents in a social home of South Jakarta.

\section{Method}

\section{Participants}

The population that is used in this study was adolescents living at the social home in South Jakarta. In South Jakarta, there is only one social home owned by the government of Jakarta, which is Social Home of Bina Remaja Taruna Jaya. Sampling using total sampling technique means that all members of the population are used as samples. Adolescents in Social Home of Bina Remaja Taruna Jaya are 50 people, so the participants for this study are 50 adolescents. The characteristics are as follows:

a. Living at Social Home of Bina Remaja Taruna Jaya in South Jakarta

b. Adolescent boys and girls aged $11-22$

c. Receive a direct education in social home for $3-$ 12 months

\section{Measures}

In this study, the data are collected with the scale method as a common measurement in psychology. According to Azwar (2004) scale method is a type of data collection submitted to the respondent or research subject through a number of questions or written statement. Scale in this research is arranged based on Likert Scale model with five categories of answers are: Strongly Agree (SA), Agree (A), Hesitate (H), Disagree (D), and strongly
disagree(SD). The scoring used for items of statements on a scale is as follows:

Table 1.

Likert Scale Assessment Table

\begin{tabular}{lcc}
\hline Alternative Answer & Favorable & Unfavorable \\
\hline Strongly Agree & 5 & 1 \\
\hline Agree & 4 & 2 \\
\hline Hesitate & 3 & 3 \\
\hline Disagree & 2 & 4 \\
\hline Strongly Disagree & 1 & 5 \\
\hline
\end{tabular}

The scale used in this study consist of social adjustment scale which is developed by Hurlock theory (2013), assertiveness scale which is adopted from Palmer and Froehner (2004), and empathy scale which is adopted from Eisenberg et al.(1997); Hoffman (2002); Colley (1998); Bierhoff (2002).

Scale in the form of questionnaires that have been prepared by researchers and tested the instrument. The result of social adjustment scale test obtained 27 valid items with alpha Cronbach range .444 .800 and the reliability value is 0.963 . Assertiveness scale test results obtained 30 valid items with alpha Cronbach range $.370-.727$ and the reliability value is .931. The test results of empathy scale obtained 17 valid items with alpha Cronbach range .325 .747 and reliability value is .912 .

Data collection using questionnaires was filled directly by adolescent of social home. The researcher gave instruction and supervised the adolescent in choosing their agreement to fill the questionnaires. They also can ask questions in case they do not understand about some items from the scale.

\section{Analysis}

The analytical method uses Bivariate Correlation to find the correlation between two variables and Multivariate Correlation to find the correlation between three variables. The hypothesis in this study will be tested through Product Moment Pearson's statistical analysis in SPSS version 22.0 for Windows.

\section{Results}

Based on the result of data analysis research on the first hypothesis, there was a significant positive 
correlation between assertiveness and social adjustment ( $r=.857$ and $p=.000)$, suggesting that the higher the assertiveness of the adolescents in social home of South Jakarta, the higher the level of social adjustment that they showed. On the other hand, the lower the assertiveness of the adolescents in a social home of South Jakarta, the lower the level of social adjustment that they showed.

Furthermore, in line with the second hypothesis, there was a significant positive correlation between empathy and social adjustment $(r=.708$ and $p=$ .000 ), meaning that the higher the empathy of the adolescents in a social home of South Jakarta, the higher the level of social adjustment that they showed. Conversely, the lower the empathy of the adolescents in a social home of South Jakarta, the lower the level of social adjustment that they showed.

The result of data analysis research on the third hypothesis with a multivariate correlation between assertiveness variable and empathy with social adjustment obtained $R$-value equal to .871 and $p=$ .000 , this means there is a significant positive correlation between assertive behavior and empathy with social adjustment to the adolescents in a social home of South Jakarta.

Based on the result of score categorization, the social adjustment has low score categorization with $\bar{X}<$ 75.9, medium score categorization $75.9 \leq \bar{X} \leq 86.1$ and high score categorization with $\bar{X}>86.1$. Then assertiveness has low score category with $\bar{X}<70$, medium score categorization $70 \leq \bar{X} \leq 110$ and high score categorization with $\bar{X}>110$. Furthermore, empathy has low score categorization with $\bar{X}<$ 47.79, medium score categorization $47.79 \leq \bar{X} \leq$ 54.21 and high categorization with $\bar{X}>54.21$. On social adjustment, the mean of findings is 104.6, it means that the social adjustment of the adolescents in a social home of South Jakarta is in the high category. Then the mean findings of assertiveness were obtained for 114.78, it means that assertiveness of the adolescents in a social home of South Jakarta is in a high category as well. Furthermore, the mean findings of empathy are obtained at 63.32, then the empathy of the adolescents in a social home of South Jakarta is in the high category. The categorization of variables is based on significant differences between the mean finding scores and the theoretical mean divided into three sections: high, medium and low (Kuncono, 2005).
This study also found the contribution of assertiveness and empathy to social adjustment of $75.9 \%$ with the result R Square $\left(R^{2}\right) .759$, that means the rest of $24.1 \%$ is a contribution of other factors that affect social adjustment that is not included in this study. Based on the Stepwise calculation, assertiveness variable contributed $73.5 \%$ to social adjustment as a result of $\mathrm{R}$ Square .735 . While the empathy variables accounted for $2.4 \%$ of social adjustment.

\section{Discussion and Conclusion}

Based on the results of the research to test the hypothesis bivariate correlation between assertiveness variable and social adjustment, there is a significant positive correlation between assertiveness and social adjustment. This shows that there is a correlation between assertiveness and social adjustment of the adolescents in the social home of South Jakarta. The result of the correlation with the positive direction shows that the higher the assertiveness, the higher the social adjustment. Similarly, the lower the assertiveness of the adolescents in the social home of South Jakarta, the lower the level of social adjustment. This is in accordance with a Rini, Bahri, and Zuliani (2016) who found a significant relationship between assertive behavior variables with social adjustment. It was concluded that assertive behavior in adolescents is closely related to social adjustment. In other words, the higher assertiveness of adolescents, the better social adjustment. With the existence of assertiveness in adolescents, it can help adolescents in making a good social adjustment with others.

The result of research to test hypothesis bivariate correlation between empathy variable with social adjustment known that there is a significant positive correlation between empathy and social adjustment. This result shows there is a correlation between empathy and social adjustment of the adolescents in the social home of South Jakarta. The result of correlation with the positive direction shows that the higher the empathy, the higher the social adjustment. Similarly, the lower the empathy of the adolescents in a social home of South Jakarta, the lower the level of social adjustment. The results of this study are in line with studies conducted by Cohen and Strayer (Supeni, 2014) which showed that subjects with high scores on aggression and maladjustment (low social adjustment) had low scores on empathy. That is, individuals who have 
low empathy cannot make good adjustments. Conversely, if adolescents have a high empathy then the adaptation of adolescents are also high.

The result of data analysis research on hypothesis with a multivariate correlation between assertiveness variable and empathy with social adjustment known that there is a positive correlation between assertive behavior and empathy to social adjustment of the adolescents in the social home of South Jakarta.

The results of the scoring categorization in this study, showing the social adjustment score in the "high" category, it means that the social adjustment of the adolescents in the social home of South Jakarta is in the high category. Then, the assertiveness score in the "high" category, meaning that assertiveness of the adolescents in the social home of South Jakarta is in the high category. Furthermore, the empathy score is in the "high" category, meaning that empathy held by the adolescents in a social home of South Jakarta is in the high category.

Then in the results of the research have known that there is a correlation between assertiveness and empathy with social adjustment of the adolescents in the social home of South Jakarta where the contribution of assertiveness and empathy to social adjustment is equal to $75.9 \%$, the contribution of assertiveness toward social adjustment equal to $73.5 \%$. While empathy contribution to social adjustment is 2, 4\%. This shows that assertiveness has a higher contribution than empathy toward the social adjustment of the adolescents in a social home of South Jakarta. Assertiveness which is the ability to communicate what one wants and feels to others is one of the millennial generation's characteristics. Millennial generation (Y generation) is a teenager born in 1980 until the 2000s. This generation is generally characterized by increased usage and familiarity with communications, media, and digital technology. Technological change and generational change often go hand in hand. That is certainly the story of the millennials and their embrace of all things digital. For them, these innovations provide

more than a bottomless source of information and entertainment and more than a new ecosystem for their social lives. Many millennials say their use of modern technology is what distinguishes them from other generations (Pew Research Center. 2010). Adolescents living at social home in South Jakarta who use advanced technology are more able to express themselves, dare to argue, and play a role in the conversation in social media. Adolescents adapt themselves more in social media not in real social environments, so the sense of empathy does not really matter in its adaptability. Furthermore, based on the contribution of both variables leaving $24.1 \%$. It involves the contribution of other variables that influence social adjustment beyond assertiveness and empathy factors. The contribution of assertiveness is much greater than empathy to the social adjustment of the adolescents in the social home shows that those who have an openness to express opinions are able to resist and express themselves well is enough to foster adolescent social adjustment. It means, nowadays it is necessary to be able to adjust to a social home.

Based on the data analysis that has been described in the previous chapter it can be concluded that there is a significant positive correlation between assertiveness and social adjustment of the adolescents in a social home of South Jakarta. Furthermore, there is a significant positive correlation between empathy and social adjustment of the adolescents in a social home of South Jakarta. There is a significant positive correlation with the positive direction between assertiveness and empathy with social adjustment of the adolescent in a social home of South Jakarta.

This research was done in the social home of South Jakarta and only have 50 participants. Future r research can expand this research to have more participants. There are also opportunities to do future research in different social home and different region to develop this study. The researcher hopes this positive correlation can be a scientific contribution to the real the social interaction context of adolescents in a social home.

\section{References}

Anita Zulkaida. 2005. Tingkah Laku Asertif pada Mahasiswa. Jakarta: Universitas Gunadarma.

Apollo. 2008. Hubungan Antara Kepercayaan Diri dan Perilaku Asertif dengan Kecemasan Berkomunikasi Lisan pada Remaja, Arkhe Th.13, No.2, hal 78 - 87. Fakultas Psikologi: Universitas Widya Mandala Madiun.

Baron, Robert A \& Byrne, Donn. 2005. Psikologi Sosial Jilid II. Jakarta: Penerbit Erlangga. 
Bierhoff, H.W. 2002. Prosocial Behaviour. New York: Psychology Press.

Eisenberg, N., Fabes, RA., Murphy, B., Karbon, M., Smith, M., \& Maszk. 1996. The Relation of Children's Dispositional Empathy-Related Responding to Their Emotionality, Regulation, and Social Function. Journal of Development Psychology, 32. 195-209.

Hoffman, M. L. 2000. Empathy and Moral Development. USA: Cambridge University Press.

Hurlock, B. 2013. Perkembangan Anak Jilid 1Edisi Keenam. Jakarta: Penerbit Erlangga.

Kuncono. 2005. Aplikasi Komputer Psikologi. Jakarta: Fakultas Psikologi Universitas Persada Indonesia YAI.

MG Supeni. 2014. Empati Perkembangan dan Pentingnya dalam Kehidupan Bermasyarakat. Vol. 40 No.1, hal 60-71. FKIP Universitas Tidar Magelang.

Mohammad Ali. 2004. Psikologi Remaja: Perkembangan Pesert Didik. Jakarta: PT. Bumi Aksara.
Palmer dan Froehner. 2002. Harga Diri Remaja: Penuntun Menumbuhkan Harga Diri Bagi Remaja. Jakarta: Gramedia

Papalia, D.E, Olds dan Feldman. 2013. Human Development. Edisi 10. Jakarta: Salemba Humanika.

Pew Research Center. 2010. Millenials: A Portrait of Generation Next (Confident, Connected, Open to Change).

Rini, Syaiful Bahri, Hetti Zuliani. 2016. Kontribusi Perilaku Asertif Remaja Terhadap Penyesuaian Sosial (Suatu Penelitian di MAN Kota Banda Aceh). Jurnal Ilmiah Mahasiswa Bimbingan dan Konseling FKIP Unsyiah. Vol.1 No.1: hal 13-27.

Saefuddin Azwar. 2004. Penyusunan Skala Psikologi. Yogyakarta: Pustaka Belajar.

Schneiders, A.A. 1960. Personal and Mental Health. USA.

Syamsu Yusuf. 2004. Psikologi Perkembangan Anak \& Remaja. Bandung: PT. Remaja Rosdokarya.

Taufik. 2012. Empati Pendekatan Psikologi Sosial. Jakarta: Rajawali Pers. 